\title{
Making Other Worlds Possible: \\ The Battle in Seattle in World-Historical Context
}

Jackie Smith, University of Pittsburgh

\begin{abstract}
Prepared for Socialism and Democracy special issue: SEATTLE+20: Movements at the Millennium
\end{abstract}

\begin{abstract}
The protests against neoliberal globalization at the 1999 ministerial meeting of the World Trade Organization were significant because they represented the first large-scale resistance gaining wide visibility among a global public. The fact that the WTO ministerial was taking place in "the belly of the beast" increased its visibility and significance. It was far from the first mass protest against globalized capitalism, and it wasn't the most global in its representation. Nevertheless, it disrupted the idea that "there is no alternative" to the neoliberal agenda, encouraged dissent from governments in the global South, and created space for critical debates about the downsides of economic globalization. For the global left, it helped focus energy and inspire hope for a different kind of globalization. Seattle thus launched a movement-building process that gave birth to the World Social Forums, which in turn advanced new movement relationships and organizing that continue today. This article describes initiatives that have developed in the wake of the Battle in Seattle, illustrating how that protest episode contributed to ongoing movement learning and mobilization that fuels popular efforts to make other worlds possible.
\end{abstract}

\section{Preface/Standpoint}

The following account of the global justice movement is shaped by my social position, experiences, and analyses I've been able to develop through engagement with other participants, observers, and analysts. I'm a veteran of the Battle in Seattle and other protests at sites of global trade negotiations in Prague, Quebec City, and Washington DC, where I participated in street protests as well as many convenings of activist groups to develop analyses of globalization and refine the tactics and strategies of the movement. The rapid sequencing of protests meant that I encountered some of the same organizations, networks, and strategies and witnessed the learning that happened as activists discussed ideas about strategy and vision and confronted their many differences. By early 2001, these conversations led to an emerging consensus that mass protests at the sites of inter-state negotiations was not productive or sustainable, and that our movements needed a new approach if we were to sustain the momentum the Seattle protest helped launch.

It was then that the call for participation in the World Social Forum meeting in Porto Alegre captured the imaginations of many thousands of global justice activists and provided a space for movement-building as well as resistance to neoliberal globalization. We were not merely protesting the global capitalist project. We were gathering to change the conversation and focus our energies on the projects and organizing work we knew was necessary not just to stop the destructive forces of capitalism, but to enable the birth of a unified movement for a different global system. Participants saw a direct link with Seattle's verbalization of a global "No" to the neoliberal project. The WSFs became a space for movements to articulate alternatives. That the first WSF generated an ongoing process of connecting and organizing was critical. Moreover, its 
generation of local and regional forums revealed a tacit understanding that these conversations had to be connected to the places people lived. They could not remain limited to the abstracted, global spaces that reinforced existing omissions and privilege. I remained as engaged as I could in this process (alongside my academic job), and was able to be part of the first U.S. Social Forum in 2007 and to serve on the National Planning Committee for the 2010 USSF in Detroit. Today I remain embedded in these networks as I organize in the Right to the City movement.

\section{Seattle's Battle in Context}

The years leading up to and 2 decades following the battle in Seattle can be read as the articulation and popularization of movement knowledge about how to change the world. In fact, we can extend our historical lens to link contemporary movements to centuries-old struggles over rights and land. A broader, world-historical viewpoint tells a story about collective work to enact a political project of grounding globalization in people's everyday experiences and in places, a process others have called "deglobalization" (Álvarez and Chase-Dunn 2019, Bello 2003, Chase-Dunn 2005). Another term used to describe at least some of deglobalization's key elements is decolonization, which highlights efforts to reorganize historically defined power structures and social relations. The contemporary wave of global justice protests thus appears as a third major wave of anti- and de-colonial resistance: the first encompasses $18^{\text {th }} \& 19^{\text {th }}$ century through post-WWII indigenous, antislavery and anticolonial movements. This was followed by the "world revolution of 1968," which encouraged new efforts to understand intersectionalities of struggles and deepen the project of decolonization. Today's "world revolution of 20xx" builds upon those lessons to support collective identities and organizing to resist unjust power structures and make other worlds possible. ${ }^{1}$

Capitalist globalization has relied on the serial disruption of people's relationships to the land and the abstraction of these material realities to make them both legible to - and available for exploitation by - states and global capital (Scott 1998). Abstraction enables not just commodification, enumeration, and management of the biosphere and human societies, but also dehumanization and de-sensitization to human suffering. It makes the routine, yet brutal, practices of capitalism both amenable to technical solutions and palatable to enough people to enable the system's continuation. As Quan observed, "[a]t the heart of savage developmentalism is structured otherness" (2012:4). In other words, myths of development and technological progress normalize systems of oppression and mask systemic violence. Thus, a key task for movements is to undermine hegemonic authority by removing the veil of civility and exposing the power structures, contradictions, and violence of global capitalism. Today, world-systemic crises have enabled these efforts to find more receptive audiences, as more widespread precarity and suffering remove "the main hidden stabilizer of the system, the optimism of the oppressed" (Wallerstein 2004: 84 -5).

The Battle in Seattle took place during a critical time in the history of the modern worldsystem when U.S. hegemony was continuing its long decline and facing new counter-hegemonic

\footnotetext{
${ }^{1}$ Icaza and Vázquez also use the analogy of waves of protest to describe the post Chiapas and Seattle protests, indicating that these struggles "are examples of events that break with the chronology of modernity" (2013:684). For more on the historical development of anti-systemic struggles see, e.g. Amin et al. (1990); Amin (2008); Arrighi et al. (1989); Boswell and Chase-Dunn (2000); Chase-Dunn and Niemeyer (2009); Manning (2017); Wallerstein (2014).
} 
challenges to its leadership, while the system was becoming more crisis-prone. Europe, China, and leaders in the global South were increasingly pursuing their own agendas in inter-state negotiations - as was evidenced in the breakdown of the Seattle WTO talks. And the brutality of capitalism's "expulsions" (Sassen 2014a, Sassen 2014b) was fueling more popular resistance and transnational movement-building. Twenty years after the Seattle WTO, we can see that episode as an important turning point. For it was at that time that the world's social movements began carving out their own global political space-autonomous from the agendas, priorities, and epistemologies of the inter-state order - where they could envision a different world and develop strategies for building it. To build upon the work of Antonio Gramsci, we might see this period as one when movements have significantly advanced the global "war of position" or “epistemological struggle" against capitalist hegemony (Icaza and Vázquez 2013).

Below I demonstrate how the global justice movement that grew in the wake of the Seattle WTO provides evidence for this claim, and consider what lessons today's global movements are generating about how to change the world. The Battle in Seattle made way for novel and lasting networks of activists working across national and other borders to improve understandings of how capitalist globalization impacts diverse communities, and how people can better work together to transform this unjust system. The World Social Forums that grew from the post-Seattle efforts disrupted dominant ideologies asserting the inevitability of neoliberal globalization (a.k.a. "progress") and provided an immensely valuable space for sustained and iterative dialogue, reflection, and organizing for well over a decade. Although the WSF process has diminished in recent years, its effects persist, providing ongoing inspiration and guidance as well as networks and resources for global social transformation. Yet, much commentary and research overlooks these critical outcomes of the WSF process, focusing instead on the supposed failures of the WSF to persist in its earlier form.

I view the global justice movement and the WSF process it generated as part of a longterm world-historical struggle between two visions for how our world might be organized. On one side are capitalist, neoliberal globalizers who have built the dominant institutions and practices that are now hegemonic. On the other side are networks of people who have, throughout history, continuously resisted the extractivist and consumerist ideologies of Western imperialism. While there is a great diversity in how such claims have been made, the ideas of human rights and democracy largely capture the prevailing sentiments of these struggles (Smith 2008). Moreover, in this early $21^{\text {st }}$ century, we can see that the late 1990 s was in fact a turning point where people were increasingly transcending national identities and political boundaries to engage with one another in a more systemic, collective project to change how the world is organized (Smith and Wiest 2013; Smith et al. Forthcoming).

The World Social Forums helped advance this struggle to re-define a global project to prioritize the voices of people, localities, and principles of human rights over corporations, globalization, and material wealth. They opened transnational spaces for collective learning and the development of new ways of thinking, fostering new networks of activists, organizations, and policy practitioners who were better equipped to work across geographic, cultural, and other divides around a shared vision and strategic orientation (Carroll 2016). These innovations in thinking and organizing generated new political projects that have re-shaped the global justice movement and expanded its reach into both global institutions and local communities. I highlight elements of just three of these strands of organizing, including the Right to the City movement, global peasants' rights struggles, and Indigenous peoples movements. I consider how these initiatives have generated networks and influence that extend from global to local contexts and 
that challenge not only the power structures sustaining the existing order but also-and more importantly - its culture-ideology of consumerism (Sklair 2001). Together these three initiatives help give vision and form to another possible world where human rights and democracy can thrive.

\section{Nurturing Ideas \& Identities}

A good deal of research has documented the important role the WSFs played in helping shape both the cognitive - i.e., movement identities and ideas - and mobilizing infrastructures of the global justice movement (See, e.g., (Sen et al. 2003, Sen and Waterman 2012, Sen 2013, Smith et al. 2011, Smith et al. 2014). Although the World Social Forums themselves no longer possess their original capacity to convene global movements, the WSF process continues in the work of the initiatives and networks it helped inspire and nurture. By challenging the claim of dominant world leaders that "there is no alternative" to the brand of neoliberal globalization they were imposing on the world, the WSF helped mobilize the creative energy of participants, expanding the repertoire of action for the global justice movement, which had primarily operated as an oppositional force. It was engaging in what Wallerstein (2004:37) refers to as "antisystemic socialization." 2 By claiming that "Another world is possible," Forum organizers disrupted dominant narratives about development and opened space for people to imagine new possibilities for society and to articulate shared global visions, values, and strategies.

The global organization of the WSF process is significant as well, since it enabled people to come together across national and cultural divides on a scale not previously seen in popular movements. The World Forums brought together people from over 100 countries in a common space, and participants represented many walks of life, ranging from peasants and slum-dwellers to academics, labor organizers and faith leaders. Public officials from municipalities and international organizations also attended. ${ }^{3}$ Even those who could not attend the WSF in person gained from the extensive online documentation of these gatherings a sense that there is an energized global "we" that has different shared ideas and visions from the mainstream.

The ability to meet people from different socioeconomic and geographic spaces allowed WSF participants to learn about how global capitalism impacted people in diverse contexts. It also allowed them to understand how the world's governments and international institutions like the World Bank and IMF advance the interests of global corporations over the needs of people and communities. Such a shared analysis of global capitalism and its varied and harmful effects is critical to bringing people together to fight for change, and the debates, dialogues, and cultural experiences the WSFs enabled helped develop movement knowledge about global strategies.

The WSF process itself benefitted from the experience and skills activists who had long worked in global contexts such as the United Nations global conferences and protests at the World Bank and G-7/8 meetings. The shared knowledge from this prior work certainly shaped the WSF's form and operating process, and it also led it to create principles and practices that would help it avoid the pitfalls and constraints - such as efforts at elite co-optation and appropriation - experienced in these other spaces (see Smith et al. 2017). In addition, practices in the WSF and related global justice networks revealed conscious efforts not to replicate colonial

\footnotetext{
${ }^{2}$ The organization of sequential and geographically dispersed forums helped support antisystemic socialization in ways that earlier mobilizations could not. In addition, the political moment of world-systemic crisis also amplifies possibilities for this kind of widespread socialization (Wallerstein 2004)

${ }^{3}$ The global spread of municipal participatory budgeting can be linked to the WSF's early meetings in Porto Alegre, Brazil.
} 
patterns of domination (Carroll 2016; Juris 2008). For instance, one important conversation was over the negative impacts of funding from corporations, governments, and foundations. The problem of the "nonprofit industrial complex" was widely critiqued in WSF panels and planning sessions. An organization of funders that recognized this problem, the Funders Network on Trade and Globalization, reflected learning among social change advocates, and a book on this topic was widely discussed and shared by activists (INCITE! Women of Color Against Violence 2007).

\section{Movement-building}

In addition to shaping the ideas that motivated global justice activism, the WSF process impacted the "mobilizing structures" that help sustain and resource movement activity. Organizations and groups seeking to operate in the WSFs needed to have or to build capacity to participate in some way. Simply having the resources to travel to the WSFs did not enable people or groups to join the organizing process or offer programming: The Forum's intentional effort to create "contact zones" (Santos 2006) that disrupted prevailing inequalities and centered the voices of oppressed groups incentivized "transversal solidarities" and resource-sharing (Carroll 2016:50). To have a voice in WSF decision-making, activists had to build unity across national and other divisions and sustain their engagement across time and place. ${ }^{4}$

The sequential organizing of the WSFs encouraged activists and groups to build intersectional ties as they developed the content of the Forum's sessions. The ability to meet activists during one Forum and re-convene at a later one encouraged collaboration to produce sessions and to otherwise engage the WSF spaces to advance organizing. Thus, activists learned new communication and planning skills and organizing models. Another way the WSFs supported movement building was by inspiring the proliferation of regional and local forums. Such connections have been key for connecting global and local activist terrains and "translating" lessons from the WSF into local contexts (Santos 2006).

\section{Post-Seattle Global Movement Initiatives}

The WSF process, including the intensive efforts that went into organizing any given global, national, or local forum helped activists and groups develop knowledge and skills relevant for working together in a system that has relied upon fueling divisions and competition between groups. Knowing that making transformative change would require unity among vast segments of the world's people encouraged many activists to engage in patient work to, for instance, provide volunteer language interpretation services and develop new listening and resourcesharing strategies (Doerr 2008, Doerr 2009, Juris 2008). Activists also used WSF spaces to deepen their understandings of one another, both by struggling together-for instance to strengthen the voices of women in Forum organizing and messaging - and by engaging in dialogues aimed at deepening understandings and developing strategies (Alvarez, Faria and Nobre 2003; Conway 2012; Vargas 2005; Smith and Doerr 2011; Moghadam 2012).

\footnotetext{
${ }^{4}$ Thus, indigenous peoples and feminist activists formed their own caucuses or dialogue spaces in the WSFs to build unity and to strategize about how to bring their analyses and struggles into WSF spaces (Conway 2012; Desai, Manisha. 2007. "The Messy Relationship between Feminisms and Globalizations." Gender and Society 21(6):797803. Karides, Marina and Thomas Poniah. 2008. "In Defense of World Social Forum Vii." Pp. 7-20 in The World and the Us Social Forums: A Better World Is Possible and Necessary, edited by J. Blau and M. Karides. Leiden, The Netherlands: Brill. Vargas, Virginia. 2005. "Feminisms and the World Social Forum: Space for Dialogue and Confrontation." Development 48(2):107-10..
} 
By connecting people in a sequence of meetings organized on multiple scales and in different places around the world, the WSF process encouraged the spread and refinement of new ideas and shared values and principles. It also encouraged and nurtured the development of movement organizing infrastructures to better support organizing across national borders and other divides. Lessons advanced through global justice movement activities is evident in the following movements that emerged from them. Interestingly, each of these cases - selected for their relative prominence in the field of possible examples - relate to struggles over land and livelihoods. They are also struggles over culture, identity and meaning. And all articulate claims for democracy and human rights. Interestingly, they all ground globalization in a place. But unlike parochial nationalist struggles, they simultaneously valorize the local and connections to the physical environment while also valuing global connections and dialogue.

\section{Right to the City Movement}

The latter part of the $20^{\text {th }}$ century saw the rise of a growing number of movements of place-based (largely urban) struggles for human rights and democracy around the world, alongside growing contestation over neoliberal globalization (Harvey 2012, Mayer 2009, Oömen, Davis and Grigolo 2016). They began mainly in the mega-cities of the global South, in the informal settlements being formed in the outer-rings of these cities as a result of mass displacement of rural residents.

Similar place-based and rights-based claims-making emerged simultaneously in different parts of the world and generated a variety of discourses and strategies. ${ }^{5}$ All center on rights that are essential to survival: housing (land), decent work at living wages, health, food and water, and political voice and "dignity." In Europe, for instance, these movements arose in response to the Maastricht Treaty and the development of a trade-focused European Union. Calls for a "social Europe" resulted in, among other initiatives, a European Charter for Safeguarding Human Rights in the City, which now has over 400 municipal parties. ${ }^{6}$ At the same time, the People's Decade for Human Rights Education helped lead an initiative for "human rights cities," buoyed by the emphasis of the 1993 UN World Conference on Human Rights emphasis on the need to strengthen local capacities and strategies for implementing human rights.

All of these streams of organizing came together in the World Social Forum, which, according to Chueca helped internationalize the right to the city (2016). The Forum of Local Authorities had convened local authorities alongside the World Social Forum since 2001, debating a draft text of a World Charter of the Right to the City (Oomen and Baumgärtel 2012:6). That Charter was formally issued following the 2004 Social Forum of the Americas in Quito, Ecuador. ${ }^{7}$ In 2007, various groups came together at the U.S. Social Forum in Atlanta to form the Right to the City Alliance. ${ }^{8}$ And the Global Right to the City Platform, formed in 2014

\footnotetext{
${ }^{5}$ As in other instances (such as the WSF), U.S. activists have been late to joining the right to the city movement, when Washington DC became the first U.S. human rights city in 2008.

${ }^{6}$ http://www.uclg-cisdp.org/en/right-to-the-city/european-charter.

${ }^{7}$ There appears to be a connection with the "Northern" rights movements identified by Chueca, as this Charter is linked to the World Urban Forum (a platform organized within UN Habitat), which met in Barcelona in September of 2004 to adopt the Charter. This Charter was developed for UN Habitat III, held in Quito Ecuador in October 2016.

${ }^{8}$ http://righttothecity.org/about/mission-history/ (See also Pastor et al. 2009; Gotham and Greenberg 2014).
} 
by a diverse coalition of NGOs and municipal agencies (many based in Brazil where the WSF was strongest), links its formation to the networks and analyses emerging from decades of UN conferences and World Social Forums during the 1990s and 2000s. ${ }^{9}$

I directly encountered these discussions when I attended the World Social Forums in 2001 and 2005 and participated in numerous regional and local social forums. At the 2005 WSF in Porto Alegre, Brazil, the PDHRE hosted a Human Rights Cities workshop of a few hundred people held under a tent. Here I witnessed explicit discussions about how groups sought to use human rights language and international law in their local struggles for dignity and justice. ${ }^{10}$ The issue of right to the city became a major focus of WSF activists at the 2007 WSF in Nairobi, when a slum near the Forum site was being demolished as activists traversed the city to attend WSF activities. Following the Detroit USSF, U.S. activists attended the 2011 WSF as part of a "Detroit to Dakar" delegation, where they began linking their own local struggles around housing and racialized displacement to the growing resistance to land grabs in Africa and other parts of the global South.

These multiple, sequential encounters among activists - linked as they were through a global network of activists, groups, websites and blogs, and movement media - contributed to the emergence of a shared global analysis of the ways globalized capitalism was impacting communities by limiting affordable housing, access to water, and the ability of residents to determine development priorities and urban design. By privileging the accumulation/extractive agendas of global trade and finance, capitalist globalization marginalizes residents of cities and communities, undermining democracy as well as communities, dignity, and even livelihoods. For many, the right to the city is thus a globalized struggle for local survival.

For those engaged in the conversations of social movements at the WSFs, it was becoming increasingly apparent that human rights — reframed through popular struggles — could provide a pathway to the kind of world many were seeking. Moreover, in the face of economic globalization and its processes of enclosure and displacement, it was important to establish people's rights to be in a place, and for that place to remain one that enabled dignified and fulfilling lives. Linking the practices and consequences of neoliberal globalization policies with specific rights violations helped movements converge around more critical and systemic analyses of global capitalism (Santos 2007b; Rajagopal 2006; Rodríguez-Garavito 2014). Thus, although many academics and liberal activists in the United States have argued that human rights was an imperialist framework that constrained activist movements, I found in spaces like the World Social Forums that human rights frames seemed helpful for bringing diverse, inter-sectional alliances together around shared projects, and for connecting some of the most oppressed groups with more privileged sectors. ${ }^{11}$

Today, the right to the city movement is thriving, and the streams I identified above have converged. Within this movement one can find people, organizations, networks and ideas that have roots in earlier activism. Following the intentionality of the WSFs, they bring together communities most impacted by global capitalism with other movement actors, municipal leaders, and international public officials. Also, my research on the WSF process has led me to engage in activism aimed at helping bring the human rights cities initiative to people in the United States. I

\footnotetext{
${ }^{9}$ http://www.righttothecityplatform.org.br/sobre-o-direito-a-cidade/

${ }^{10}$ These discussions, moreover, resonated with others I encountered in my research on the WSF process.

${ }^{11}$ Other scholars, such as Petchesky (2003), Rodríguez-Garavito (2014), Desai (2015), and Sikkink (2017) among others, have made similar observations.
} 
helped found the Pittsburgh Human Rights City Alliance, ${ }^{12}$ and that led to my work as cofounder of the U.S. Human Rights Cities Alliance. This work in cities reflects the project of "grounding globalization" in the sense that we are centering place and people's need for connection to and rights to the land while fostering global conversations and strengthening relationships between localities and the global human rights movement (see also Gready and Lockey 2019). For instance, the U.S. Human Rights Cities Alliance helps connect local communities with the United Nations human rights institutions, and it is currently helping mobilize a campaign to engage U.S. cities and communities in the UN's Universal Periodic Review of the U.S. human rights record. ${ }^{13}$ In addition, regular convenings of Human Rights City organizers include participation from activists outside the United States, and efforts to strengthen international ties among human rights cities activists are growing.

\section{Via Campesina \& Peasant Struggles}

Another important and highly visible case where global justice activism has helped fuel the growth of significant transformative movement initiatives is in the work of Via Campesina, a worldwide network of peasant organizations and small farmers that began in Latin America. ${ }^{14}$

Via Campesina came together in the early 1990s to address the problems economic globalization brought for small-scale farmers. Today, it represents around 300 million small farmers across five continents. The organization was able to use the WSF process to build its network of members and allies while promoting peasant perspectives and analyses on globalized food production and how best to resist it. The organization put forward the idea of "food sovereignty" as a key demand. This concept stresses the rights of food producers to control the land they farm and determine what and how they produce. It also demands rights for consumers to healthy and culturally appropriate, ecologically sustainable food. ${ }^{15}$ Emphasis on the social and cultural elements of food production and related rights are at the forefront.

The story of Via Campesina reinforces the ideas shared above, showing how movement actors have developed in the course of struggle and engagement with international institutions and movements. Not only has Via Campesina's strategy been shaped by the lessons from past movement experiences, making it wary of how it engages with UN processes where civil society voices become submerged beneath those of corporate and state actors (Mann 2008), but its ability to gain prominence in the field of transnational movement organizations results from global justice activism. Activists in Via Campesina used the World Social Forums to build their transnational activist connections, and to show how international trade policies impact small farmers and, by extension, everyone's access to food. They introduced the notion of "food sovereignty" to the wider activist community, and this idea gained widespread resonance at the WSFs. Forum panels around food sovereignty helped popularize Via's work and inspired global support (Borras 2008; Martínez-Torres and Rosset 2010; McMichael 2008; McKeon 2013). For instance, I watched the language of Detroit food justice activists evolve over the course of USSF organizing. Whereas they were initially using language of "food security" inherited from

\footnotetext{
${ }^{12}$ When I moved to Pittsburgh in 2011, the city had already passed a Proclamation naming Pittsburgh the fifth human rights city in the United States. Significantly, that initiative was led by youth who were part of the American Friends Service Committee, one of the key U.S. organizations participating in the WSF and USSF process and supporting participation of grassroots and people of color activists.

${ }^{13}$ See the UPR Cities Project: http://wiki.humanrightscities.mayfirst.org/index.php?title=UPR_Cities_Project

$14 \mathrm{http}: / /$ viacampesina.org/en/

15 https://viacampesina.org/en/food-sovereignty/
} 
mainstream discourses, following the USSF - where the U.S. Food Sovereignty Alliance was advanced - this language had shifted to "food sovereignty." By connecting food producers and consumers, Via Campesina has played a major role in building a powerful force to challenge both the culture and structures of corporate globalization.

Food sovereignty has helped embolden small farmers whose livelihoods are imperiled by global agribusiness, conveying legitimacy and moral force to their human rights claims. It has helped radicalize global discourse around food, rejecting "food security" — promoted by powerful states and international institutions - to emphasize the human rights of producers and consumers. In practical terms, the idea of food sovereignty helped expand markets for smallscale producers, supporting organization by consumers who help reinforce farmer demands. The notion of food sovereignty is also spreading in official policy circles, through Via Campesina's engagement with the Food and Agricultural Organization and other regional bodies and governments (McKeon 2013; 2015). Language around food sovereignty is increasingly found in official policy of organizations like the Organization of American States and in the national constitutions of numerous states (Mann 2014).

Via Campesina's efforts to promote food sovereignty and peasant rights have most recently been advanced with the UN General Assembly's 2018 adoption of the UN Declaration on the Rights of Peasants and Other People Working in Rural Areas. Via Campesina has worked over nearly two decades for the Declaration, with the aim of eventually realizing a legally binding international Convention on the rights of peasants. ${ }^{16}$ As Edelman argues, the campaign for the peasant rights declaration reflected strategies that social movements have developed over time, increasingly using the international arena to "deepen and institutionalize new conceptions of 'rights' that go beyond those codified in existing international instruments" (2011: 83). Their work has helped strengthen the global human rights regime:

normative understandings of human rights have expanded over long historical time, in ongoing processes of political contention. Rights that were once considered inconceivable are now either accepted or seen as legitimate topics for discussion (Edelman 2011: 82).

This campaign illustrates how movements have learned to use the international arena to address structural inequities and injustices and legitimate claims for economic and social rights of marginalized groups (Nelson and Dorsey 2008). The Declaration on the Rights of Peasants significantly advances internationally recognized human rights with international recognition of rights for an economically defined group. It also validates and reinforces prior precedents in human rights law, laying a foundation for future precedents that would: advance collective and cultural rights; provide legal support for peasants' claims against transnational corporations; redefine food as a right rather than a commodity; advance legal recognition of people's rights to a healthy environment; promote gender equity; and prioritize human rights over economic claims. The Declaration also defends the right to the protection of traditional knowledge relevant to plant genetic resources for food and agriculture and the equitable enjoyment of the benefits of technology, including genetic research (Smith and Schroering 2018).

If Via Campesina and its allies are successful in achieving a binding international convention, this would represent a huge milestone in advancing human rights globally. But even

\footnotetext{
${ }^{16}$ Edelman (2011) traces the history of the campaign, situating the early conversations in 2000 at Via Campesina's organizational convenings. The initial draft of the declaration was produced at the 2002 conference in Jakarta.
} 
without a formal treaty, it is clear from past research on human rights that "expressive aspects of human rights law" like the Convention on the Rights of Peasants can impact behaviors of powerful actors (Edelman 2011:97). As Risse, Ropp and Sikkink have argued, when grassroots movements popularize knowledge of global human rights norms and use them to monitor practices and pressure public authorities for compliance, they contribute to a normative "spiral," where pressure from advocates gradually brings government practices into alignment with rights norms (Risse, Ropp and Sikkink 1999). ${ }^{17}$ The cases explored here show that movement capacity for doing this have grown.

\section{Indigenous Peoples Movements}

The emergence of indigenous peoples as more visible and prominent global actors is another key legacy of early global justice activism. Despite difficulties and contention, indigenous peoples movements were able to claim and use WSF spaces to bring the perspectives of people engaged in the longest historical struggle against capitalist globalization to a larger global audience (Becker and Koda 2011, Conway 2017, Conway 2012). Activists coming to the global justice movement from a variety of places were able to encounter indigenous leaders and organizations and learn new ways of seeing the world. Indigenous people brought a civilizational critique to global movement spaces, and the WSF provided a platform that could amplify this critique and challenge activists to consider new ways of thinking about the other worlds that could be possible. Two ideas in particular, have gained attention from activists around the world because of the movement spaces generated by post-Seattle global justice activism, namely rights of Mother Earth, and sumac kawsay or buen vivir.

The idea of endowing nature-Pachamama-with rights is one that can restore humans' relationships with the planet that sustains life. Western religious traditions and industrial mindsets required the separation of humans from our ecosystems to support the exploitative and extractive practices necessary for capitalist accumulation. But climate change and related environmental threats have compelled a different approach, one that has a long and successful history in most indigenous cultures. Thus, as a framework for thinking, it helps support policies and actions that would respond to the urgent environmental and health challenges our society faces today.

In addition to providing a different lens on humans' relationship with nature, indigenous voices brought new ideas to challenge the basic logic of capitalism. While critiquing the materialism of capitalism, buen vivir suggests a hopeful and inspiring path that can generate much more creative responses from those introduced to it than does more confrontational anticapitalist discourse. Yet, for many steeped in Western culture, the idea of organizing a society around anything but material acquisition and economic growth is unheard of. This is largely due to the hegemony of global capitalism, which prevents opportunities for alternative discourses and ways of thinking to emerge. Global movement spaces like the WSFs created such spaces where

\footnotetext{
${ }^{17}$ Illustrating how the group plans to use the Declaration to advance its larger goals, Via Campesina's website states: "As peasants all over the world, we are going to mobilize and we will join hands in our respective countries to lobby for the establishment of policies and strategies that contribute towards recognition, enforcement and accountability. Violations of our rights through land grabbing, forced evictions, gender discrimination, lack of social protection, failing rural development policies and criminalization can now, with the formal international recognition of this Declaration, be addressed with increased legal and political weight" Via Campesina. 2018. "Finally, Un General Assembly Adopts Peasant Rights Declaration! Now Focus Is on Its Implementation.".
} 
counter-hegemonic ideas could be expressed and popularized. Such openings have been important for the expression of indigenous knowledge. According to Martin and Wilmer:

[I]ndigenous rights and the norms on which they rest arise from the 'bottom' and are asserted 'upward' in order to mobilize an international consensus, which in turn can be marshaled in support of indigenous peoples against state and transnational power. (2008: 584)

Thus, in the "movement learning networks" of the WSF and other global movement spaces (McMichael 2008:54), indigenous expressions of "living well" helped promote "alternative ontologies," which "make what is 'virtually unthinkable' in dominant capitalist narratives into viable political projects" (McMichael 2008:44).

As I've argued elsewhere, the global justice movement and WSF process has facilitated the global spread of ideas like food sovereignty, buen vivir and rights of Mother Earth to a much broader, interconnected global audience of activists, organizations, politicians and publics (Smith 2014). Such language is finding its way into national constitutions and other official documents, including those of multilateral institutions. It is also capturing the imaginations of a growing global public that is eager to see movement to address our interlinked global crises.

Making these ideas more visible and resonant in global spaces is the fact that the movement conversations I've traced here were taking place alongside parallel efforts of indigenous activists to build power within the United Nations system. Working in institutions, indigenous movements defended indigenous cultures and traditions while challenging states' very legitimacy and authority by questioning basic geopolitical assumptions about state boundaries and historical claims on indigenous lands. Using claims to human rights, indigenous peoples helped make space to question fundamental assumptions and principles of the inter-state order. Their work to establish a Working Group on Indigenous Peoples (1982), ${ }^{18}$ led to the International Year (1993) and two consecutive International Decades on Indigenous Peoples (1994-2014), ${ }^{19}$ and the creation of a Permanent Forum on Indigenous Issues in 2000 and a UN Declaration on the Rights of Indigenous Peoples in 2007 (Morgan 2007, Sargent 2012). ${ }^{20}$ These have all helped lift up indigenous peoples as global actors while encouraging indigenous groups to articulate their claims in globally resonant ways and to build their global political power. ${ }^{21}$ This march through the institutions reflects a strategy of other marginalized groups (Scoones 2018), demonstrating an important movement strategy of working over the long-term and in both movement and official spaces to transform discourses and cultural priorities by altering the institutional structures that perpetuate hegemony.

\section{Seattle +20 \& Emergent Movement Knowledge}

Our vantage point 20 years after the Battle in Seattle suggests that today's global justice movement has developed in transformative ways, and perhaps representing a third wave of

\footnotetext{
${ }^{18}$ https://www.ohchr.org/EN/Issues/IPeoples/Pages/MandateWGIP.aspx

19 The first International Decade of People of African Descent was 1995-2004, followed by the second in 2005-2014 (https://www.ohchr.org/EN/Issues/IPeoples/Pages/InternationalDecade.aspx).

${ }^{20} \mathrm{https}$ ://www.ohchr.org/EN/Issues/IPeoples/Pages/Declaration.aspx. For the complete timeline of indigenous work in the League of Nations and United Nations see: https://www.un.org/development/desa/indigenouspeoples/aboutus.html

${ }^{21}$ People of African descent have sought to follow the leadership of indigenous groups, and have established the International Decade of People of African Descent (2015-2024).
} 
decolonial struggles advancing more cohesive collective visions of a new world-system. This wave of movements is a substantial advance in the global "war of position" against capitalist hegemony in the sense that movements have intentionally come together to challenge the very logic of capitalism. In fact, Icaza and Vázquez characterize the Chiapas rebellion and the Battle of Seattle 22 as significant "epistemic struggles" that

challenge the monopoly of modernity over the representation and the appropriation of the real. They can be read as decolonial moves in that they bring to visibility the voices that have been silenced; they open a public space where actions of political freedom and dignity can happen. (Icaza and Vázquez 2013:696)

The elements of the "world revolution of 20xx" I've summarized here demonstrate how decolonial struggles enable the emergence of new (or formerly invisible) collective identities and global actors, including urban dwellers, peasants, and indigenous peoples, among others. These identities and sense of global agency has deepened and strengthened movement alliances across diverse groups and identities, helping clarify the commonalities of people's experiences of dispossession and displacement. Language of human rights and claims to place/land and political voice have helped bring unity to this diverse and loosely-knit "movement of movements."

This strengthened agency and sense of shared struggle has also supported more widespread and robust antisystemic socialization, which in turn has helped create political spaces that relate to, but are independent of, inter-state institutions. Thus, networks emerging from the WSF process have forged both tactical and strategic connections with municipal governments, inter-governmental officials, and political elites from counter-hegemonic states. The net effect of these efforts is that U.S. hegemony in the world-system, and the capitalist system itself faces threats beyond those posed by other state or hegemonic competitors. The challenge movements are bringing, from above and from below, is altering discourses in global political spaces in ways that question the basic practices of capitalism and threaten the legitimacy of the prevailing order. More importantly, movements have begun to come together in new ways to advance local and global projects to displace capitalist development with other models for buen vivir.

Table 1 outlines what I think are some of the key insights growing from the projects described above. In sum, we can identify three main terrains of struggle that impact not only public policy and agendas, but that also shape the larger culture as well as movement practices and organizational forms. Movement experiences - both historical and in this most recent political moment - have generated points of unity that have reinforced efforts to build alliances across national and other differences.

Table 1: Global Movement Terrains and Unifying Concepts

\begin{tabular}{|l|l|}
\hline Terrains of struggle & Unifying concepts \\
\hline Cultural & Human rights as collective \\
\hline Organizational & Intersectionality \& relational \\
\hline Institutional & Relationship to place \& land \\
\hline
\end{tabular}

\footnotetext{
22 These authors stress the Eurocentric biases of academia, and their coupling of the 1994 Chiapas rebellion with the Battle in Seattle demonstrates how the view from the global South alters understandings of politically important moments. Indeed, activists in Seattle were clear that their protests drew upon the analyses and claims arising from Chiapas.
} 
Each of our three cases revealed that movement actors are engaging in work that targets culture, organizations, and state and inter-state institutions. These three terrains of struggle are all

mutually supportive and essential to the broader transformative work these initiatives envision. ${ }^{23}$

Movements' experiences have generated lessons about what language and conceptual frameworks help build unity across diverse groups. Building this unity is a critical aspect of antisystemic struggle, as globalized capitalism and its "structured otherness" has required the active cultivation of difference and structural divisions among the world's human beings and between humans and the environment. By forging connections and relationships across divides, movements help weaken the ability of the system to dehumanize and desensitize those whose labor and acquiescence is critical to its operation.

Human rights has proved an effective unifying discourse and framework that has emerged simultaneously in different sectors and spaces as people have worked to frame their critiques of capitalist globalization and demands for dignity. Interestingly, the three cases also highlight collective, rather than individual, rights. The right to the city and rights of peasants and indigenous peoples depend not upon one's status as an individual but upon one's membership in a particular group of people. These collective rights also contain individual's rights to material and social needs. Thus, we might argue that human rights is being taken up as a "de-colonial fighting instrument" (Baraka 2017) by today's decolonizing world revolution of 20xx.

While human rights provides a unifying focal point, understandings of intersectionality and organizational practices and principles that have emerged from movements have facilitated cooperation across diverse groups and collectives. In order for what could be paralyzing contention to generate new knowledge about building transformative social movements, activists must disrupt conventional deliberative practices and intentionally engage in what Doerr calls "political translation" and "active listening" (Doerr 2018). Models and leadership skills that aid in this work are artefacts of prior struggles that serve as foundations for today's (Polletta 2002).

Finally, in regard to institutional dimensions, these cases reveal the common theme that people need and want to be connected to a place. They need secure access to land to ensure both human and ecosystem survival. Economic globalization has largely been a project to deemphasize place and community as it has displaced people from traditional lands and communities. In this period of late capitalism, the expelled have no remaining place to go, and communities - both ecological and human ones - are losing their reproductive capacities. So what these cases suggest is that today's revolutions are holding the ground they have left and working to re-articulate a culture of connection to the land, place, and community.

\section{Conclusion}

In sum, the global justice movement that gained global prominence at the 1999 WTO protests in Seattle created spaces where grassroots activists in cities around the world could come

23 These observations parallel those of Carroll, whose investigation of Transnational Alternative Policy Groups revealed a "repertoire of alternative knowledge production and mobilization" that included; challenging hegemonic knowledge, engaging with dominant institutions, supporting grassroots participation and capacity building, building solidarity thru dialogical knowledge production and mobilization, integrating theory and practice, creating spaces for reflection and invention, systematizing and disseminating alternative knowledge, and prefiguring alternative futures from present practices (2016:142). 
together to develop new identities and global networks, articulate shared analyses of how local experiences were being shaped by economic globalization, and advance strategies for using human rights as a mobilizing framework and as a tool for amplifying their power using international law and institutions. They have advanced new terrains of struggle and unifying concepts that help provide unity and sustain the energy and commitment of earlier generations of activists. The right to the city, peasant, and indigenous movements build on the legacies of the battle in Seattle and the collected movement knowledge that grows from centuries of struggles for a more just and equitable world. Such knowledge is a vital resource for today's world revolution of $20 \mathrm{xx}$.

\section{References}

Álvarez, Rebecca and Christopher Chase-Dunn. 2019. "Forging a Diagonal Instrument for the Global Left: The Vessel." Journal of World-Systems Research 25(2).

Alvarez, Sonia, Nalu Faria and Miriam Nobre. 2003. "Another (Also Feminist) World Is Possible: Constructing Transnational Spaces and Global Alternatives from the Movements." Pp. 199-206 in Challenging Empires: The World Social Forum, edited by J. Sen, A. Anand, A. Escobar and P. Waterman: Third World Institute: Available in Pdf format at www.choike.org.

Amin, Samir, Giovanni Arrighi, Andre Gunder Frank and Immanuel Wallerstein, eds. 1990. Transforming the Revolution: Social Movements and the World-System. New York: Monthly Review Press.

Amin, Samir. 2008. The World We Wish to See. New York: Monthly Review Press.

Arrighi, Giovanni, Terence K. Hopkins and Immanuel Wallerstein. 1989. Antisystemic Movements. New York: Verso.

Baraka, Ajamu. 2017. "Malcolm X and Human Rights in the Time of Trumpism: Transcending the Masters Tools." Black Agenda Report.

Becker, Marc and Ashley N. Koda. 2011. "Indigenous Peoples and Social Forums " in Handbook of the World Social Forums, edited by J. Smith, S. Byrd, E. Reese and E. Smythe. Boulder: Paradigm Publishers.

Bello, Walden. 2003. Deglobalization: New Ideas for Running the World Economy: Zed Books.

Borras Jr., Santunino M. . 2008. "La Vía Campesina and Its Global Campaign for Agrarian Reform." Pp. 91-122 in Transnational Agrarian Movements: Confronting Globalization, edited by S. M. Borras Jr., M. Edelman and C. Kay. Malden, MA: Wiley-Blackwell.

Boswell, Terry and Christopher Chase-Dunn. 2000. The Spiral of Capitalism and Socialism. Boulder, Co.: Lynne Rienner Publishers.

Carroll, William. 2016. Expose, Oppose, Propose: Alternative Policy Groups and the Struggle for Global Justice. New York: Zed.

Chase-Dunn, Christopher. 2005. "Social Evolution and the Future of World Society." Journal of World Systems Research 11(2):171-92.

Chase-Dunn, Christopher and Richard Niemeyer. 2009. "The World Revolution of 20xx." Pp. 35-57 in Transnational Political Spaces; Agents, Structures, Encounters, edited by M. Albert, G. Bluhm, J. Helmig, A. Leutzsch and J. Walter. Frankfurt, Germany: CampusVerlag. 
Chueca, Eva Garcia. 2016. "Human Rights in the City and the Right to the City: Two Different Paradigms Confronting Urbanisation." Pp. 103-20 in Global Urban Justice: The Rise of Human Rights Cities, edited by B. Oomen, M. F. Davis and M. Grigolo. New York: Cambridge University Press.

Conway, Janet. 2017. "The Study of Social Movements in the Modern-Colonial World System." Pp. 17-34 in Social Movements and World-System Transformation, edited by J. Smith, M. Goodhart, P. Manning and J. Markoff. New York: Routledge.

Conway, Janet M. 2012. Edges of Global Justice. New York: Routledge.

Desai, Manisha. 2007. "The Messy Relationship between Feminisms and Globalizations." Gender and Society 21(6):797-803.

Desai, Manisha. 2015. Subaltern Movements in India: Gendered Geographies of Struggle against Neoliberal Development. New York: Routledge.

Doerr, Nicole. 2008. "Deliberative Discussion, Language and Efficiency in the World Social Forum Process." Mobilization 13(4):395-411.

Doerr, Nicole. 2009. "Listen Carefully: Democracy Brokers at the European Social Forums." $\mathrm{PhD}$ Doctoral Dissertation, Political Science, European University Institute, Florence.

Doerr, Nicole. 2018. Political Translation: How Social Movement Democracies Survive. New York: Cambridge University Press.

Edelman, Marc and Carwil James. 2011. "Peasants' Rights and the UN System: Quixotic Struggle? Or Emancipatory Idea Whose Time Has Come?". Journal of Peasant Studies 38(1):81-108.

Figueroa Helland, Leonardo E. and Pratik Raghu. 2017. "Indigeneity Vs. 'Civilization': Indigenous Alternatives to the Planetary Rift in the World-System Ecology." in Social Movements and World-System Transformation, edited by J. Smith, M. Goodhart, P. Manning and J. Markoff. New York: Routledge.

Gotham, Kevin Fox and Miriam Greenberg. 2014. Crisis Cities: Disaster and Redevelopment in New York and New Orleans. New York: Oxford University Press.

Gready, Paul and Liz Lockey. 2019. "Rethinking Human Rights in York as a Human Rights City." Political Quarterly. doi: https://doi.org/10.1111/1467-923X.12733.

Harvey, David. 2012. Rebel Cities: From the Right to the City to the Urban Revolution. New York: Verso.

Icaza, Rosalba and Rolando Vázquez. 2013. "Social Struggles as Epistemic Struggles." Development and Change 44(3):683-704.

INCITE! Women of Color Against Violence. 2007. The Revolution Will Not Be Funded: Beyond the Non-Profit Industrial Complex. Cambridge, MA: South End Press.

Juris, Jeffrey. 2008. "Spaces of Intentionality: Race, Class and Horizontality at the United States Social Forum." Mobilization 13(4):353-72.

Karides, Marina and Thomas Poniah. 2008. "In Defense of World Social Forum Vii." Pp. 7-20 in The World and the Us Social Forums: A Better World Is Possible and Necessary, edited by J. Blau and M. Karides. Leiden, The Netherlands: Brill.

Mann, Alana. 2008. "Spaces for Talk: Information and Communication Technologies (ICTs) and Genuine Dialogue in an International Advocacy Movement." Asian Social Science 4(10):3-14.

Mann, Alana. 2014. Global Activism in Food Politics: Power Shift. New York: Palgrave MacMillan. 
Manning, Patrick. 2017. "Linking Social Movement Networks, 1989-1992: Southeast Asia, Africa, and South America." Pp. 61-76 in Social Movements and World-System Transformation, edited by J. Smith, M. Goodhart, P. Manning and J. Markoff. New York: Routledge.

Martin, Pamela and Franke Wilmer. 2008. "Transnational Normative Struggles and Globalization: The Case of Indigenous Peoples in Bolivia and Ecuador." Globalizations 5(4):583-98.

Martínez-Torres, María Elena and Peter M. Rosset. 2010. "La Vía Campesina: The Birth and Evolution of a Transnational Social Movement." Journal of Peasant Studies 37(1):149-75.

Mayer, Margit. 2009. "The 'Right to the City' in the Context of Shifting Mottos of Urban Social Movements." City 13(2-3):362-74. doi: http://dx.doi.org/10.1080/13604810902982755.

McKeon, Nora. 2013. "'One Does Not Sell the Land Upon Which the People Walk:' Land Grabbing, Transnational Rural Social Movements, and Global Governance." Globalizations 10(1):105-22.

McKeon, Nora. 2015. "La Via Campesina: The 'Peasants' Way' to Changing the System, Not the Climate." Journal of World-Systems Research 21(2):241-49.

McMichael, Philip. 2008. "Peasants Make Their Own History, but Not Just as They Please." Pp. 37-60 in Transnational Agrarian Movements: Confronting Globalization, edited by S. M. Borras Jr., M. Edelman and C. Kay. Malden, MA: Wiley-Blackwell.

Moghadam, Valentine. 2012. Globalization and Social Movements: Islamism, Feminism and the Global Justice Movement, Second Edition. Boulder, CO: Rowman \& Littlefield.

Morgan, Rhiannon. 2007. "On Political Institutions and Social Movement Dynamics: The Case of the United Nations and the Global Indigenous Movement." International Political Science Review 28(3):273-92.

Nelson, Paul and Ellen Dorsey. 2008. New Rights Advocacy: Changing Strategies of Development and Human Rights NGOs. Washington DC: Georgetown University Press.

Oomen, Barbara and M. Baumgärtel. 2012. "Human Rights Cities." Pp. 709-29 in The Sage Handbook of Human Rights, edited by A. Mihr and M. Gibney. http://www.researchgate.net/publication/277775662 Human Rights Cities: Sage.

Oömen, Barbara, Martha F. Davis and Michele Grigolo, eds. 2016. Global Urban Justice: The Rise of Human Rights Cities. New York: Cambridge University Press.

Pastor, Manuel Jr., Chris Benner and Martha Matsuoka. 2009. This Could Be the Start of Something Big. Ithaca, NY: Cornell University Press.

Petchesky, Rosalind Pollack. 2003. Global Prescriptions: Gendering Health and Human Rights. New York: Zed Books.

Polletta, Francesca. 2002. Freedom Is an Endless Meeting. Chicago: University of Chicago Press.

Quan, H.L.T. 2012. Growth against Democracy: Savage Developmentalism in the Modern World. Lanham, MD: Lexington Books.

Rajagopal, Balakrishnan. 2006. "Counter-Hegemonic International Law: Rethinking Human Rights and Development as a Third World Strategy." Third World Quarterly 27(5):76783.

Risse, Thomas, Stephen C. Ropp and Kathryn Sikkink, eds. 1999. The Power of Human Rights: International Norms and Domestic Change. New York: Cambridge University Press. 
Rodríguez-Garavito, César. 2014. "Towards a Human Rights Ecosystem." Pp. 39-46 in Debating the Endtimes of Human Rights: Activism and Institutions in a Neo-Westphalian World, edited by D. Lettinga and L. van Troost. The Hague: Amnesty International.

Santos, Boaventura de Sousa. 2006. The Rise of the Global Left: The World Social Forums and Beyond. London: Zed.

Santos, Boaventura de Sousa. 2007. "Human Rights as an Emancipatory Script? Cultural and Political Conditions." Pp. 3-40 in Another Knowledge Is Possible, edited by B. d. S. Santos. New York: Verso.

Sargent, Sarah. 2012. "Transnational Networks and United Nations Human Rights Structural Change: The Future of Indigenous and Minority Rights." International Journal of Human Rights 12(1):123-51.

Sassen, Saskia. 2014a. Expulsions: Brutality and Complexity in the Global Economy. Cambridge, MA: Belknap/Harvard University Press.

Sassen, Saskia. 2014b. "Expelled: Humans in Capitalism's Deepening Crisis." Journal of WorldSystems Research 19(2):198-201. doi: http://dx.doi.org/10.5195/jwsr.2013.495.

Scoones, Ian. 2018. "Ongoing Conversations: Realising an Emancipatory Rural Politics in the Face of Authoritarian Populism " Open Democracy. (https://www.opendemocracy.net/ian-scoones/ongoing-conversations-realisingemancipatory-rural-politics-in-face-of-authoritarian-pop).

Scott, James C. 1998. Seeing Like a State: How Certain Schemes to Improve the Human Condition Have Failed. New Haven: Yale University Press.

Sen, Jai, Anita Anand, Arturo Escobar and Peter Waterman, eds. 2003. Challenging Empires: The World Social Forum: Third World Institute: Available in Pdf format at www.choike.org.

Sen, Jai and Peter Waterman, eds. 2012. The World Social Forum: Critical Explorations, Volume 3. New Delhi: OpenWord.

Sen, Jai. 2013. "The Wsf over Thirteen Years: Learning by Doing?". ALAI, América Latina en Movimiento 484:http://www.alainet.org/active/63440.

Sikkink, Kathryn. 2017. Evidence for Hope: Making Human Rights Work in the 21st Century. New Jersey: Princeton University Press.

Sklair, Leslie. 2001. The Transnational Capitalist Class. Cambridge: Blackwell.

Smith, Jackie. 2008. Social Movements for Global Democracy. Baltimore, Md.: Johns Hopkins University Press.

Smith, Jackie, Scott Byrd, Ellen Reese and Elizabeth Smythe, eds. 2011. Handbook of World Social Forum Activism. Boulder: Paradigm Publishers.

Smith, Jackie and Nicole Doerr. 2011. "Democratic Innovation in the U.S. And European Social Forums." Pp. 339-59 in Handbook of the World Social Forums, edited by J. Smith, S. Byrd, E. Reese and E. Smythe. Boulder: Paradigm Publishers.

Smith, Jackie. 2014. "Counter-Hegemonic Networks and the Transformation of Global Climate Politics: Rethinking Movement-State Relations." Global Discourse: An Interdisciplinary Journal of Current Affairs and Applied Contemporary Thought 4(1):1-19.

Smith, Jackie, Samantha Plummer and Melanie M. Hughes. 2017. "Transnational Social Movements and Changing Organizational Fields in the Late-20th and Early-21st Centuries ". Global Networks 17(1):3-22. doi: 10.1111/glob.12152. 
Smith, Jackie, Basak Gemici, Samantha Plummer and Melanie M. Hughes. 2018. "Transnational Social Movement Organizations and Counter-Hegemonic Struggles Today." Journal of World-Systems Research 24(2):372-403. DOI: https://doi.org/10.5195/jwsr.2018.850.

Smith, Jackie, Marina Karides, Marc Becker, Dorval Brunelle, Christopher Chase-Dunn, Donatella della Porta, Rosalba Icaza, Jeffrey Juris, Lorenzo Mosca, Ellen Reese, Peter Jay Smith and Rolando V'azquez. 2014. Global Democracy and the World Social Forums, 2nd Edition. Boulder, Colorado: Paradigm Publishers.

Smith, Jackie and Caitlin Schroering. 2018. "Global Peasant Declaration Represents Huge Advance for Human Rights." Common Dreams. (https://www.commondreams.org/views/2018/12/18/global-peasant-declarationrepresents-huge-advance-human-rights).

Vargas, Virginia. 2005. "Feminisms and the World Social Forum: Space for Dialogue and Confrontation." Development 48(2):107-10.

Via Campesina. 2018. "Finally, Un General Assembly Adopts Peasant Rights Declaration! Now Focus Is on Its Implementation."

Wallerstein, Immanuel. 2004. World-Systems Analysis: An Introduction. Durham, N.C.: Duke University Press.

Wallerstein, Immanuel. 2014. "Antisystemic Movements, Yesterday and Today." Journal of World-Systems Research 20(2):158-72. doi: http://dx.doi.org/10.5195/jwsr.2014.593. 